\title{
Zinc, copper and iron concentrations in the plasma and diets of lactating Nigerian women
}

\author{
BY CARL M. F. MBOFUNG* \\ Department of Biochemistry, College of Medical Sciences, Bendel State University, \\ Ekpoma, Nigeria \\ AND TOLA ATINMO \\ Department of Human Nutrition, College of Medicine, University of Ibadan, \\ Ibadan, Nigeria
}

(Received 30 April 1984 - Accepted 15 November 1984)

1. Zinc, copper, iron, protein and energy intakes of 232 lactating women (consuming self-selected diets during the first 3 months post-partum) were computed from food intake values obtained using a $3 \mathrm{~d}$ dietary-recall method. Non-pregnant, non-lactating women (100) served as controls. Blood samples of subjects were also analysed for packed cell volume and haemoglobin concentrations as well as for plasma $\mathrm{Zn}, \mathrm{Cu}$ and Fe levels by atomic absorption spectrophotometry.

2. Except for Fe, intakes of all nutrients measured were significantly lower than recommended dietary allowances for lactation. Daily mean (and SD) $\mathrm{Zn}, \mathrm{Cu}, \mathrm{Fe}(\mathrm{mg})$, protein $(\mathrm{g})$ and energy (MJ) intakes for lactating women were $8 \cdot 2(1 \cdot 6), 1 \cdot 6(0 \cdot 5), 29 \cdot 0(5 \cdot 8), 52 \cdot 4(9 \cdot 2)$ and $10 \cdot 21$ respectively. There was a significant intercorrelation between the different nutrients in the diet.

3. Mean (and SD) plasma $\mathrm{Zn}, \mathrm{Cu}$ and Fe concentrations $(\mu \mathrm{g} / \mathrm{l})$ during the first 3 months of lactation were 666.0 $(76.0), 1290 \cdot 0(150 \cdot 0)$ and $730 \cdot 0(185)$ respectively. These values were significantly $(P<0.05)$ lower in the case of $\mathrm{Zn}$ and $\mathrm{Fe}$ and higher in the case of $\mathrm{Cu}$ than those of non-pregnant, non-lactating women. Maternal plasma levels of the trace elements also varied significantly with nutritional status as indexed by haemoglobin status.

4. Correlation analysis between dietary and plasma trace element concentrations was significant for $\mathrm{Zn}(r 0.26$, $P<0.0001)$ and $\mathrm{Fe}(r 0.17, P<0.05)$. Dietary protein intake was significantly correlated with plasma $\mathrm{Zn}(r 0 \cdot 18$, $P<0.005)$ and $\mathrm{Fe}(r 0.12, P<0.05)$.

5. While maternal weight, arm circumference and skinfold thickness measurements tended to decrease with increase in the period of lactation, growth performance of entirely breast-fed babies was satisfactory as at the 12 th week post-partum.

The process of lactation is nutrient demanding and, as a result, lactating mothers represent a group of particular interest as their nutritional requirements are usually very high. Unfortunately, however, there is still a wide gap of knowledge concerning the extent to which these mothers, particularly those in the low socio-economic groups of the Third World countries, are meeting the recommended dietary allowance (RDA) of certain essential nutrients. The present paper concerns their trace element nutrition. Although many studies have been carried out on the dietary nutrient intake of lactating mothers (Karmarkar \& Ramakrishnan, 1960; Picciano \& Guthrie, 1976; Geissler et al. 1978; Vaughan et al. 1979; Vuori et al. 1980; Moser \& Reynolds, 1983), these are mostly from the advanced countries of the world and very few provide information on the essential trace element profile of diets eaten during lactation.

Research findings in the literature have emphasized the essential roles of some of these trace elements (e.g. zinc, copper and iron) in normal growth, development and health of humans. As with other nutrients, maternal dietary requirements for trace elements are raised during the process of lactation (World Health Organization (WHO), 1965, 1970, 1973). Generally, knowledge of trace element nutrition among Africans is limited. In Nigeria, particularly, it is not known to what extent lactating mothers, such as those living within

\footnotetext{
* Present address: Department of Biochemistry, Obafemi Awolowo College of Health Sciences, Ogun State University, Ago-Iwoye, Nigeria.
} 
a low socio-economic environment, are meeting their dietary requirements for these nutrients. A report of growth performance of Nigerian infants entirely breast-fed during the first 3 months (Omololu et al. 1981) suggests that breast milk is adequate in quantity and quality during this period. This may imply either that maternal dietary intake levels of these nutrients together with other nutrients are adequate or that, where dietary levels are insufficient, there is increased absorption or that maternal tissues and stores are depleted in favour of milk synthesis. In the latter case it is speculated that maternal stores and physiological levels of these nutrients may be low. The exact effect of lactation on physiological levels of these trace elements in Nigerians has not previously been reported.

The purpose of the present study was to determine the plasma and dietary $\mathrm{Zn}, \mathrm{Cu}$ and Fe levels of lactating Nigerian women during the first 3 months of lactation and to characterize the relation between the dietary intake and blood plasma levels as well as to examine the influence of such factors as lactational age and maternal nutritional status on the distribution of dietary and plasma levels of these nutrients.

\section{EXPERIMENTAL}

\section{Study area and subjects}

Subjects for the study were recruited at the Adeoyo State Hospital, situated in the indigenous area of the city of Ibadan. The study population consisted of 232 lactating mother and child pairs all of a low socio-economic class, randomly selected from groups of mothers who had just given birth or who had come for postnatal clinics with their babies. The selection exercise was guided by certain factors: only mother and child pairs who were healthy (as judged by the physician from a detailed clinical examination) and also willing to co-operate in the study were selected. In addition, the mothers had to be those who intended entirely to breast-feed their babies during the first 3 months of lactation. Mothers were fully briefed on the objectives of the study and were informed that they would receive no special benefits as a result of the study. However, subjects had the privilege of early attention from the paediatrician on all visits to the postnatal immunization clinic. Non-pregnant, non-lactating women (100) of comparable age and socio-economic group were used as the control group for the lactating mothers.

\section{Anthropometric measurements}

Mothers and their infants were seen at the 4 th week post-partum and at weeks 8 or 12 , or both, post-partum. At each visit, measurements of height, weight and arm circumference of mothers, and the weight, length and head circumference of the babies were taken according to the methods of Jelliffe (1966).

\section{Collection and analysis of blood samples}

Mothers were advised to come to the clinic after fasting. Between 09.00 and 11.00 hours, when each subject was fully rested and seated, about $10-15 \mathrm{ml}$ blood were collected from the antecubital vein with minimum stasis using stainless-steel and non-pyrogenic needles fitted to disposable and metal-free plastic syringes. The blood was put into labelled heparinized tubes and subsequently centrifuged and the plasma collected and stored in polyethylene vials at $-20^{\circ}$ until required for analysis. A small portion of each of the blood samples collected was used for packed cell volume and haemoglobin determination. Haemoglobin was analysed by the cyanmethaemoglobin reaction (International Committee for Standardization in Haematology, 1967). Plasma albumin was analysed by the bromocresol method (McPherson \& Everard, 1972). The accuracy of analysis for plasma albumin was assessed using control sera (Welcontrol normal bovine; Wellcome Foundation Ltd, Bexleyheath, Kent). 
Plasma $\mathrm{Zn}, \mathrm{Cu}$ and $\mathrm{Fe}$ concentrations were determined by atomic absorption spectrophotometry using a Perkin-Elmer Model 403 atomic absorption spectrophotometer (PerkinElmer Corp., Norwalk, Conn. USA) fitted with a $100 \mathrm{~mm}$ flat-head burner. Each plasma sample was analysed for $\mathrm{Zn}$ in duplicate following a 1:3 dilution with glycerol-de-ionized water $(5: 95, v / v)$ (Butrimovitz, 1977). Samples for $\mathrm{Cu}$ and $\mathrm{Fe}$ analysis were diluted 1:2 with glycerol-de-ionized water $(5: 95, \mathrm{v} / \mathrm{v})$ (Zaino, 1967). For each batch of analysis the diluent was used in setting the base-line reading of the instrument while the instrument was standardized with working standard solutions prepared by diluting specific volumes of stock samples (obtained as zinc nitrate, product no. 14150 ; ferric nitrate, product no. 14140 ; and cupric nitrate, product no. 14139 from BDH Chemicals Ltd, Poole, Dorset) to appropriate known concentrations.

To avoid the contamination of samples during the analytical process, all containers were soaked in acid overnight, rinsed with distilled and de-ionized water before washing with metal-free detergent (Decon 75; Gallenkamp Co. Ltd, London) in 0.1 M-EDTA. The containers were then rinsed with copious amounts of glass-distilled and de-ionized water and oven dried at $70^{\circ}$. Containers so treated were metal-free as distilled, de-ionized water rinsings from them did not show any trace of minerals.

In order to monitor the accuracy and precision of the method of analysis, specific volumes of standard control sera obtained from the US Center for Disease Control were diluted in the same way as the test samples for each batch of analyses. Analyses of such treated standard sera for $\mathrm{Zn}, \mathrm{Cu}$ and $\mathrm{Fe}$ during each batch gave an average of 95, 93 and $94 \%$ respectively of the reference values.

\section{Assessment of daily dietary intake}

The meal patterns of the subjects were similar to those described by Abakada \& Hussain (1980). The daily dietary intake of each subject was carefully assessed by the same person on three different occasions by means of a pre-tested and standardized $24 \mathrm{~h}$ dietary-recall method. Duplicate samples of foods and meals identical to those consumed by subjects were collected from the homes of subjects or bought from the same food vendors from whom subjects were in the habit of buying their food. Such samples were homogenized, adding distilled and de-ionized water where necessary, and dried and later pulverized to a fine powder using a mechanical grinder with steel blades (Moulinex Model 531). Trace elements in sub-samples of the food items were determined using solutions of ashed samples by atomic absorption spectrophotometry (dry-ashing at $450^{\circ}$ for $4 \mathrm{~h}$ ). The accuracy of the process was determined by use of standard reference material (SRM 1568, rice flour) obtained from the US National Bureau of Standards. Such analysis provided results within a minimum of $94 \%$ of the reference value in each case. All glassware and containers used had been thoroughly washed in acid and rinsed several times in glass-distilled and de-ionized water. Sub-samples of the food were also analysed for total protein content by the microKjeldahl technique using a Technicon AutoAnalyzer (Technicon Instruments Co. Ltd, Basingstoke). The total energy content of the individual samples was determined by bomb calorimetry using a ballistic bomb calorimeter (model CB-370, Gallenkamp Co. Ltd). Food intake values were converted into nutrient intake values using the results of the chemical analyses of sub-samples of food.

\section{Statistical treatment of results}

Conventional statistical methods as contained in BMDP computer package (BMDP, 1979) were used in the statistical treatment of values obtained. Regression coefficients and $t$ values were considered as statistically significant for values of $P<0.05$. 


\section{RESULTS}

The mean values of plasma $\mathrm{Zn}, \mathrm{Cu}, \mathrm{Fe}$ and albumin concentration as well as the mean values for haemoglobin status are presented in Table 1 along with values obtained from the non-pregnant, non-lactating controls. In all cases, the mean values for lactating mothers were significantly $(P<0.05)$ different from those of the control group. Frequency distributions of plasma $\mathrm{Zn}, \mathrm{Fe}$ and $\mathrm{Cu}$ concentrations of the lactating mothers during the first 3 months of lactation are shown in Fig. 1. Plasma $\mathrm{Zn}$ concentrations ranged between 360 and $800 \mu \mathrm{g} / 1$ while those for $\mathrm{Cu}$ ranged from 990 to $1950 \mu \mathrm{g} / 1$ and $\mathrm{Fe}$ from 350 to $980 \mu \mathrm{g} / 1$. Of the 232 lactating mothers studied, $11.9 \%$ had a plasma $\mathrm{Zn}$ concentration of less than $500 \mu \mathrm{g} / 1$, while only $3 \cdot 2 \%$ had a plasma $\mathrm{Zn}$ concentration greater than $700 \mu \mathrm{g} / 1$. More than $28 \%$ of plasma $\mathrm{Cu}$ values were higher than $1300 \mu \mathrm{g} / 1$ while about $20 \%$ fell between 990 and $1180 \mu \mathrm{g} / 1$. As for plasma Fe concentrations, more than $45 \%$ of the individual values were below $600 \mu \mathrm{g} / 1$.

The effect of the stage of lactation on the distribution of plasma trace elements and other biochemical variables was examined using one-way analysis of variance of the values obtained at the $4 \mathrm{th}, 8 \mathrm{th}$ and $12 \mathrm{th}$ weeks of lactation. The results (Table 2) indicate a significant variation in the distribution of plasma levels of each of the variables at the different stages of lactation.

A significant correlation was observed between stage of lactation and each of the following: plasma $\mathrm{Zn}(r 0.19, P<0.05)$, plasma Cu $(r-0.36, P<0.001)$, plasma $\mathrm{Fe}(r 0.15$, $P<0.02)$, albumin $(r 0.13, P<0.01)$. Paired $t$ test analysis (Table 3) of measurements of haemoglobin status, packed cell volume and albumin levels as well as body-weight, arm circumference and triceps skinfold thickness taken at the 4th and 12th weeks of lactation in the same individuals showed several significant differences. As much as $10 \%$ of skinfold thickness measured at the 4 th week of lactation was lost by the 12 th week of lactation. Similar analysis carried out on only ten women in the control group during the 4th and 12 th weeks showed no significant changes.

Nutrient intake. The mean daily $\mathrm{Zn}, \mathrm{Cu}, \mathrm{Fe}(\mathrm{mg})$, energy $(\mathrm{MJ})$ and protein $(\mathrm{g})$ intakes

Table 1. Concentrations of plasma trace elements, albumin and haemoglobin and anthropometric measurements of Nigerian women during the first 3 months of lactation

(Mean values and standard deviations)

\begin{tabular}{|c|c|c|c|c|c|}
\hline & \multicolumn{2}{|c|}{$\begin{array}{l}\text { Lactating } \\
\text { women (LW) } \\
\text { (n 232) }\end{array}$} & \multicolumn{2}{|c|}{$\begin{array}{l}\text { Controls* }(\mathrm{C}) \\
\quad(n 100)\end{array}$} & \multirow[b]{2}{*}{$(\mathrm{LW} / \mathrm{C}) \times 100^{\dagger}$} \\
\hline & Mean & SD & Mean & SD & \\
\hline Zinc $(\mu \mathrm{g} / 1)$ & $666 \cdot 0$ & 76.0 & $1120 \cdot 0$ & $185 \cdot 0$ & $59 \cdot 5$ \\
\hline Copper $(\mu \mathrm{g} / 1)$ & $1290 \cdot 0$ & $150 \cdot 0$ & $1156 \cdot 0$ & $140 \cdot 0$ & $112 \cdot 0$ \\
\hline Iron $(\mu \mathrm{g} / 1)$ & $730 \cdot 0$ & $185 \cdot 0$ & $890 \cdot 0$ & $190 \cdot 0$ & $81 \cdot 4$ \\
\hline Albumin $(\mathrm{g} / \mathrm{l})$ & $31 \cdot 0$ & $4 \cdot 0$ & $37 \cdot 0$ & $9 \cdot 0$ & 83.8 \\
\hline Haemoglobin $(\mathrm{g} / \mathrm{l})$ & $107 \cdot 0$ & $9 \cdot 0$ & $110 \cdot 0$ & $11 \cdot 0$ & $97 \cdot 3$ \\
\hline Weight $(\mathrm{kg})$ & $54 \cdot 3$ & $8 \cdot 2$ & $55 \cdot 7$ & $15 \cdot 4$ & $102 \cdot 6$ \\
\hline Mid-arm circumference $(\mathrm{mm})$ & 244 & 31 & 257 & 30 & $105 \cdot 3$ \\
\hline $\begin{array}{l}\text { Triceps skinfold } \\
\text { thickness }(\mathrm{mm})\end{array}$ & $12 \cdot 5$ & $8 \cdot 9$ & $12 \cdot 0$ & $10 \cdot 9$ & $98 \cdot 4$ \\
\hline
\end{tabular}

* Controls were non-pregnant, non-lactating women of comparable age to the lactating women.

$\dagger$ Values for lactating women expressed as a percentage of those for non-pregnant, non-lactating women (controls). 


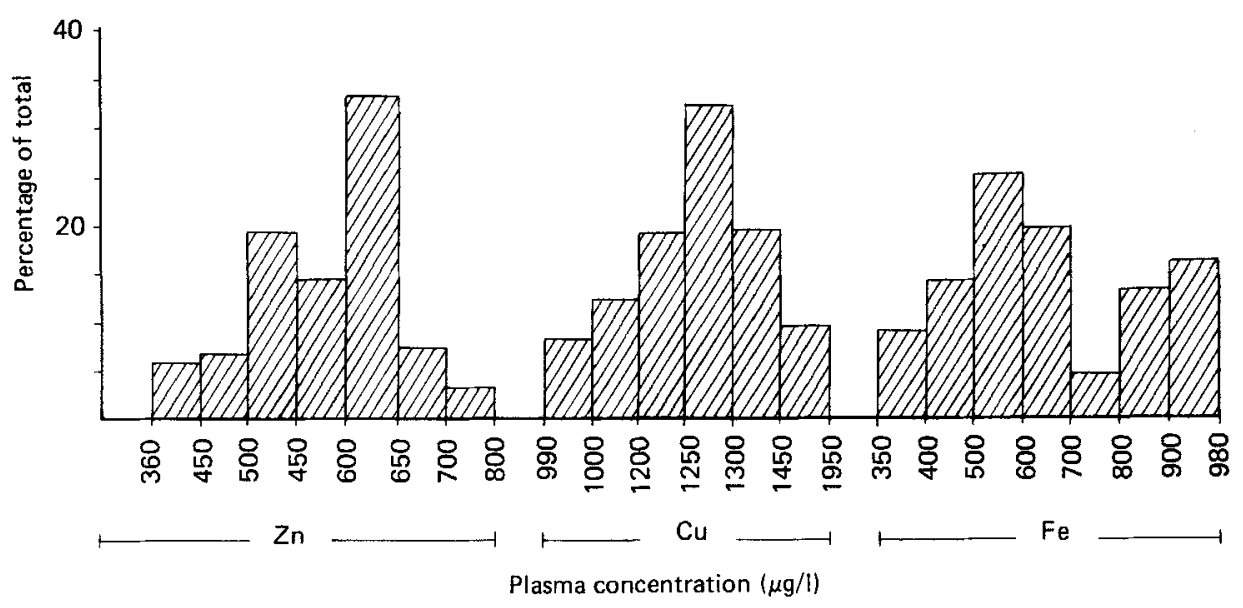

Fig. 1. Frequency distribution of plasma concentrations $(\mu \mathrm{g} / 1)$ of zinc, copper and iron in Nigerian mothers during the first 3 months of lactation.

of the lactating mothers were $8 \cdot 2,1 \cdot 6,29 \cdot 0,10 \cdot 21$ and $52 \cdot 4$ respectively (Table 4 ). Compared with the mean daily dietary intakes of the control group, the percentage increases for lactating mothers were: $\mathrm{Zn} \mathrm{17,} \mathrm{Cu} \mathrm{7,} \mathrm{Fe} \mathrm{55,} \mathrm{energy} 18$ and protein 22. Despite the apparent increase in dietary nutrient intake levels, maternal dietary intakes during the first 3 months of lactation were only $30,57,85$ and $69 \%$ respectively of the RDA (WHO, 1970, 1973; Food and Agriculture Organization (FAO)/WHO, 1973) for $\mathrm{Zn}, \mathrm{Cu}$, energy and protein during lactation. Mean dietary Fe intake on the other hand was more than $100 \%$ of the RDA. Comparing observed mean dietary intakes with recommended allowances, the RDA for dietary $\mathrm{Zn}$ was taken as $27.5 \mathrm{mg}$ according to WHO (1973). Fe intake was computed from the WHO (1970) recommendations assuming that $10 \%$ of energy intake was of animal origin. Although no RDA has been set for $\mathrm{Cu}$ intake by lactating women, the estimate of $50 \mu \mathrm{g} / \mathrm{kg}$ body-weight set by WHO (1973) for men was assumed to apply to women and $4 \mu \mathrm{g}$ was estimated as the additional amount required for the process of lactation. The RDA for energy was based on body-weight and estimated using the recommendations of the FAO (1957) and also making an allowance of $2.09 \mathrm{MJ}$ for lactation, while dietary protein

Table 2. Effect of stage of lactation on concentrations of plasma trace elements and albumin in lactating Nigerian women

(Mean values and standard deviations)

\begin{tabular}{|c|c|c|c|c|c|c|c|c|c|}
\hline \multirow[b]{2}{*}{ Stage of lactation (weeks) } & \multirow[b]{2}{*}{$n$} & \multicolumn{2}{|c|}{$\begin{array}{c}\text { Zinc } \\
(\mu \mathrm{g} / \mathrm{l})\end{array}$} & \multicolumn{2}{|c|}{$\begin{array}{c}\text { Copper } \\
(\mu \mathrm{g} / 1)\end{array}$} & \multicolumn{2}{|c|}{$\begin{array}{c}\text { Iron } \\
(\mu \mathrm{g} / \mathrm{l})\end{array}$} & \multicolumn{2}{|c|}{$\begin{array}{l}\text { Albumin } \\
(\mathrm{g} / 1)\end{array}$} \\
\hline & & Mean & SD & Mean & SD & Mean & SD & Mean & SD \\
\hline 4 & 67 & $650 \cdot 0$ & $61 \cdot 0$ & $1370 \cdot 0$ & $160 \cdot 0$ & $660 \cdot 0$ & $190 \cdot 0$ & $31 \cdot 0$ & $3 \cdot 0$ \\
\hline 8 & 76 & $658 \cdot 0$ & $76 \cdot 0$ & $1310 \cdot 0$ & $150 \cdot 0$ & $768 \cdot 0$ & $170 \cdot 0$ & $34 \cdot 0$ & $4 \cdot 0$ \\
\hline 12 & 89 & $684 \cdot 0$ & $83 \cdot 0$ & $1230 \cdot 0$ & $120 \cdot 0$ & $750 \cdot 0$ & $180 \cdot 0$ & $33 \cdot 0$ & $4 \cdot 0$ \\
\hline One-way analysis of variance: $F$ & & \multicolumn{2}{|c|}{$4 \cdot 37^{* *}$} & \multicolumn{2}{|c|}{$16 \cdot 90^{* * *}$} & \multicolumn{2}{|c|}{$4 \cdot 19^{*}$} & \multicolumn{2}{|c|}{$6.9 * *$} \\
\hline Correlation coefficient: $r$ & & \multicolumn{2}{|c|}{$0 \cdot 19^{*}$} & \multicolumn{2}{|c|}{$-0 \cdot 36^{* * *}$} & \multicolumn{2}{|c|}{$0 \cdot 15^{*}$} & \multicolumn{2}{|c|}{$0 \cdot 13^{*}$} \\
\hline
\end{tabular}

* $P<0.05, \quad * * P<0.01$, *** $P<0.001$. 
Table 4. Daily zinc, copper, iron, energy and protein intakes of lactating Nigerian women

(Mean values and standard deviations)

\begin{tabular}{|c|c|c|c|c|c|c|}
\hline \multirow[b]{2}{*}{ Nutrient } & \multicolumn{2}{|c|}{ Lactating women } & \multicolumn{2}{|c|}{ Controls } & \multirow{2}{*}{$\begin{array}{l}\text { Percentage } \\
\text { increase* }\end{array}$} & \multirow{2}{*}{$\begin{array}{l}\text { Percentage } \\
\text { of RDA } \dagger \\
\text { for lactation }\end{array}$} \\
\hline & Mean & SD & Mean & SD & & \\
\hline $\mathrm{Zn}(\mathrm{mg} / \mathrm{d})$ & $8 \cdot 2$ & 1.6 & $7 \cdot 0$ & 1.5 & $17 \cdot 0$ & 30 \\
\hline $\mathrm{Cu}(\mathrm{mg} / \mathrm{d})$ & 1.6 & 0.5 & 1.5 & $0 \cdot 4$ & $7 \cdot 0$ & 57 \\
\hline $\mathrm{Fe}(\mathrm{mg} / \mathrm{d})$ & $29 \cdot 0$ & $5 \cdot 8$ & $18 \cdot 7$ & 7.8 & $55 \cdot 0$ & 104 \\
\hline Energy (MJ/d) & $10 \cdot 21$ & $1 \cdot 50$ & 8.66 & $1 \cdot 50$ & $18 \cdot 0$ & 85 \\
\hline Protein $(\mathrm{g} / \mathrm{d})$ & 52.4 & $9 \cdot 2$ & $43 \cdot 0$ & $12 \cdot 0$ & $22 \cdot 0$ & 69 \\
\hline
\end{tabular}

* Increase in intake of lactating women expressed as a percentage of the intake of the control group.

$\dagger$ RDA, recommended dietary allowance for $\mathrm{Zn}$ was taken as $27.5 \mathrm{mg} / \mathrm{d}$ after the World Health Organization (WHO, 1973) estimates; Fe intake level of $28.0 \mathrm{mg} / \mathrm{d}$ was derived from WHO (1970) assuming that $10 \%$ of energy intake was derived from animal sources; $\mathrm{Cu}$ allowances were calculated assuming the WHO (1973) estimates of $50 \mathrm{mg} / \mathrm{kg}$ per $\mathrm{d}$ for men; energy allowances were derived using the equation energy $=123.4$ body-weight ${ }^{1 \cdot 73}$ after the Food and Agriculture Organization (FAO, 1957) and making an additional allowance of 2.3 MJ for lactation; dietary protein allowances were calculated assuming a protein quality with a net protein utilization of $60 \%$ and adding $28.0 \mathrm{~g}$ for lactation (WHO, 1973).

requirements were computed assuming a protein quality with a net protein utilization of $60 \%$ and making an additional allowance of $28 \mathrm{~g}$ for lactation according to $\mathrm{FAO} /$ WHO (1973).

The distribution of daily dietary trace element intake is shown in Fig. 2. Daily $\mathrm{Zn}$ intake ranged between 5.0 and $13.0 \mathrm{mg}$ with more than $55 \%$ of the individual intakes falling below $9.0 \mathrm{mg}$. Only about $9.5 \%$ of the study population consumed diets with a $\mathrm{Zn}$ content in excess of $10.0 \mathrm{mg} / \mathrm{d}$. Dietary $\mathrm{Cu}$ intakes also showed wide variations with individual intakes ranging from as low as 0.6 to $3.0 \mathrm{mg} / \mathrm{d}$. Intakes were skewed to the left with most of the levels $(77 \%$ ) falling below $2.0 \mathrm{mg} / \mathrm{d}$. Individual daily $\mathrm{Fe}$ intakes ranged between 17.0 and

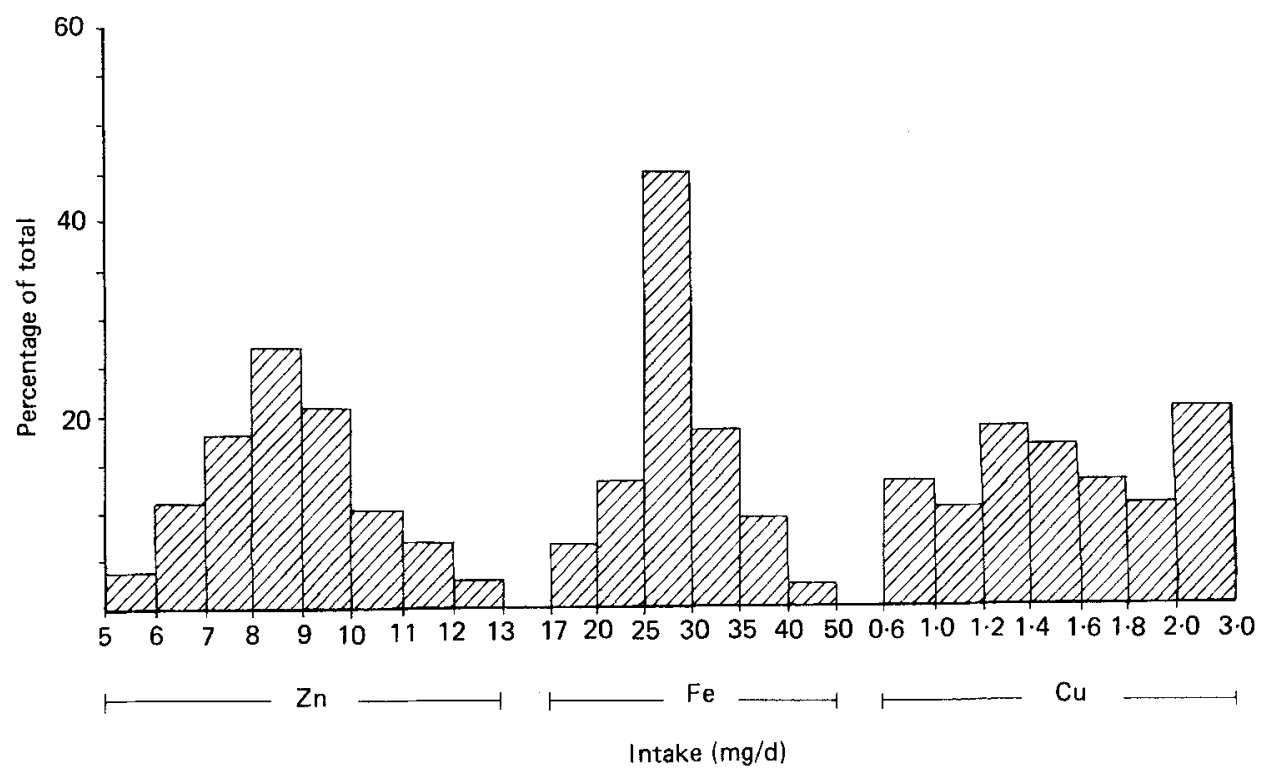

Fig. 2. Frequency distribution of dietary intakes $(\mathrm{mg} / \mathrm{d})$ of zinc, iron and copper in lactating Nigerian mothers. 
Table 5. Correlation (r) between dietary nutrient intakes of lactating Nigerian women

\begin{tabular}{llllllll}
\hline \hline & $\mathrm{Zn}$ & $\mathrm{Fe}$ & $\mathrm{Cu}$ & Protein & Energy \\
\hline $\mathrm{Zn}$ & 1.00 & 0.56 & $0.53^{*}$ & $0.65^{*}$ & $0.50^{*}$ \\
$\mathrm{Fe}$ & - & 1.00 & $0.60^{*}$ & $0.51^{*}$ & $0.40^{*}$ \\
$\mathrm{Cu}$ & - & - & 1.00 & $0 \cdot 41^{*}$ & $0.57^{*}$ \\
Protein & - & - & - & 1.00 & 0.53 \\
& Energy & - & - & - & - & $1 \cdot 00$ \\
\hline
\end{tabular}

$$
\text { * } P<0.0001
$$

Table 6. Correlation (r) between plasma trace element concentrations and dietary nutrient intake levels of lactating Nigerian women

\begin{tabular}{|c|c|c|}
\hline $\begin{array}{c}\text { Plasma trace } \\
\text { element }\end{array}$ & $\begin{array}{l}\text { Dietary nutrient } \\
\text { intake }\end{array}$ & $r$ \\
\hline Zinc & $\begin{array}{l}\text { Zn } \\
\text { Protein } \\
\text { Energy }\end{array}$ & $\begin{array}{l}0 \cdot 26^{* * *} \\
0.18^{* *} \\
0.01\end{array}$ \\
\hline Copper & $\begin{array}{l}\mathrm{Cu} \\
\text { Protein } \\
\text { Energy }\end{array}$ & $\begin{array}{l}-0.04 \\
-0.08 \\
-0.10\end{array}$ \\
\hline Iron & $\begin{array}{l}\mathrm{Fe} \\
\text { Protein } \\
\text { Energy }\end{array}$ & $\begin{array}{l}0.17^{* *} \\
0.12^{*} \\
0.03\end{array}$ \\
\hline
\end{tabular}

Table 7. Distribution of dietary nutrient intake and plasma trace elements according to nutritional status (as indexed by haemoglobin status) in lactating Nigerian women

(Mean values and standard deviations)

\begin{tabular}{|c|c|c|c|c|c|c|c|}
\hline \multirow{2}{*}{$\begin{array}{l}\text { Group no.... } \\
\text { Haemoglobin } \\
\text { status } \\
(\mathrm{g} / \mathrm{l}) \ldots \\
n \ldots \\
\text { Element }\end{array}$} & \multicolumn{2}{|c|}{$\begin{array}{c}1 \\
\text { Low } \\
(\leqslant 99 \cdot 0) \\
51\end{array}$} & \multicolumn{2}{|c|}{$\begin{array}{c}2 \\
\text { Moderate } \\
(100 \cdot 0-109 \cdot 9) \\
56\end{array}$} & \multicolumn{2}{|c|}{$\begin{array}{c}3 \\
\text { Normal } \\
\left(\begin{array}{l}\geqslant 110 \cdot 0) \\
105\end{array}\right.\end{array}$} & \multirow{2}{*}{$\begin{array}{c}\text { One way } \\
\text { analysis } \\
\text { of variance } \\
F\end{array}$} \\
\hline & Mean & $\mathrm{SD}$ & Mean & SD & Mean & SD & \\
\hline \multicolumn{8}{|c|}{ Dietary intake $(\mathrm{mg} / \mathrm{d})$} \\
\hline $\mathrm{Zn}$ & $7 \cdot 9$ & 1.8 & $8 \cdot 5$ & 1.6 & $8 \cdot 0$ & $1 \cdot 6$ & $2 \cdot 02$ \\
\hline $\mathrm{Cu}$ & $1 \cdot 6$ & 0.5 & $1 \cdot 7$ & 0.5 & $1 \cdot 6$ & 0.6 & $0 \cdot 26$ \\
\hline $\mathrm{Fe}$ & $27 \cdot 0$ & $6 \cdot 3$ & $28 \cdot 6$ & $7 \cdot 3$ & $30 \cdot 0$ & $5 \cdot 2$ & $3 \cdot 90^{*}$ \\
\hline \multicolumn{8}{|c|}{ Plasma concentration $(\mu \mathrm{g} / \mathrm{l})$} \\
\hline $\mathrm{Zn}$ & $560 \cdot 0$ & $120 \cdot 0$ & $604 \cdot 0$ & $100 \cdot 0$ & $680 \cdot 0$ & $60 \cdot 0$ & $4 \cdot 81^{* *}$ \\
\hline $\mathrm{Cu}$ & $1280 \cdot 0$ & $220 \cdot 0$ & $1304 \cdot 0$ & $120 \cdot 0$ & $1220 \cdot 0$ & $160 \cdot 0$ & $2 \cdot 90^{*}$ \\
\hline $\mathrm{Fe}$ & $540 \cdot 0$ & $100 \cdot 0$ & $590 \cdot 0$ & $160 \cdot 0$ & $690 \cdot 0$ & $140 \cdot 0$ & $3 \cdot 70^{*}$ \\
\hline
\end{tabular}

$$
* P<0.05, * * P<0.01 \text {. }
$$


Table 8. Growth increment of breast-fed babies ( $0-3$ months) of Nigerian women

(Mean values and standard deviations)

\begin{tabular}{|c|c|c|c|c|c|c|c|c|c|c|c|c|}
\hline \multirow[b]{2}{*}{ Sex } & \multicolumn{2}{|c|}{$\begin{array}{l}\text { Birth wt } \\
(\mathrm{g})\end{array}$} & \multicolumn{2}{|c|}{$\begin{array}{l}\text { Wt gain* } \\
\text { (g) }\end{array}$} & \multicolumn{2}{|c|}{$\begin{array}{l}\text { Birth length } \\
(\mathrm{mm})\end{array}$} & \multicolumn{2}{|c|}{$\begin{array}{l}\text { Length gain } \\
\text { (mm) }\end{array}$} & \multicolumn{2}{|c|}{$\begin{array}{c}\text { Head } \\
\text { circumference } \\
(\mathrm{mm})\end{array}$} & \multicolumn{2}{|c|}{$\begin{array}{c}\text { Head } \\
\text { circumference } \\
\text { gain } \\
(\mathrm{mm})\end{array}$} \\
\hline & Mean & SD & Mean & SD & Mean & SD & Mean & SD & Mean & SD & Mean & SD \\
\hline $\begin{array}{l}\hat{O}(n 93) \\
\text { q }(n 98)\end{array}$ & $\begin{array}{l}3060 \\
2960\end{array}$ & $\begin{array}{l}360 \\
360\end{array}$ & $\begin{array}{l}2579 \\
2461\end{array}$ & $\begin{array}{l}529 \\
608\end{array}$ & $\begin{array}{l}486 \\
481\end{array}$ & $\begin{array}{l}15 \\
15\end{array}$ & $\begin{array}{l}102 \\
103\end{array}$ & $\begin{array}{l}24 \\
26\end{array}$ & $\begin{array}{l}347 \\
342\end{array}$ & $\begin{array}{r}22 \\
9\end{array}$ & $\begin{array}{l}54 \\
59\end{array}$ & $\begin{array}{l}25 \\
25\end{array}$ \\
\hline Total & 3030 & 370 & 2518 & 572 & 483 & 15 & 102 & 25 & 345 & 17 & 56 & 25 \\
\hline
\end{tabular}

* At 12 th week post-partum.

$50.0 \mathrm{mg}$ and were normally distributed, with about $45 \%$ of individual intakes falling between 25.0 and $30.0 \mathrm{mg}$, while about $30 \%$ of intakes were in excess of $30.0 \mathrm{mg} / \mathrm{d}$.

The interrelations between dietary nutrients are shown in Table 5. Generally there was a high correlation $(P<0.0001)$ between the different nutrients. In particular, there was a high correlation between protein intake level and level of intake of $\mathrm{Zn}(r 0.65), \mathrm{Fe}(r 0.51)$ and $\mathrm{Cu}(r 0.41)$.

Correlations between dietary and plasma trace elements (Table 6) were significant in the case of $\mathrm{Zn}(r 0.26, P<0.0001)$ and $\mathrm{Fe}(r 0.17, P<0.05)$. The relation between dietary protein and plasma $\mathrm{Zn}$ was positive and significant; the same was true in the case of plasma Fe.

The haemoglobin levels of individuals were taken as an index of their nutritional status and the subjects were divided into three groups based on their haemoglobin status: group $1, \leqslant 99.9 \mathrm{~g} / 1$ (low); group 2, 100.0-109.9 $\mathrm{g} / 1$ (moderate); group 3, $\geqslant 110.0 \mathrm{~g} / \mathrm{l}$ (normal) (see Table 7). Of the subjects, $21 \%$ were in the low group, $35 \%$ in the moderate group and $44 \%$ in the normal group. Dietary nutrient intake according to these groupings showed significant variations only with respect to dietary $\mathrm{Fe}(F 3.90, P<0.02)$. Plasma $\mathrm{Zn}, \mathrm{Cu}$ and Fe levels, however, showed significant variations in their distribution according to the different groups.

Growth performances of the entirely breast-fed infants are shown in Table 8. Only 191 children (with accurately known birth weight, length and head circumference measurements) were studied. All the infants showed significant and satisfactory increases in all measurements by the 12th week post-partum. The fastest changes were evident in the body-weight measurements, which changed at an average rate per week of $7.0 \%$ of that at birth.

\section{DISCUSSION}

Recent reports in the literature indicate that the plasma $\mathrm{Zn}$ levels of pregnant Nigerian women (Atinmo et al. 1980), like those of their counterparts elsewhere (Halsted et al. 1968; Hambidge \& Droegmueller, 1974; Schraer \& Calloway, 1974; Jameson, 1976), are usually significantly lower than those of non-pregnant, non-lactating women. The present study further indicates that up to the 3rd month post-partum, the plasma levels of $\mathrm{Zn}$ and of Fe in lactating Nigerian women entirely breast-feeding their babies are, relatively, still lower than those of non-pregnant, non-lactating women. This observation is, however, different from that of Moser \& Reynolds (1983) who studied twenty-three well-nourished American women. Two factors commonly associated with low plasma levels of these nutrients in 
pregnancy are the physiological increase in blood volume and the change in the hormonal profile of the blood. It is, however, known that in lactation, blood volume as well as blood oestrogen levels return to normal shortly after parturition (Halsted et al. 1968). While the observation of a significant positive correlation between plasma trace element concentration and the duration of lactation may suggest the effect of post-partum changes in blood and hormonal levels, the relatively low plasma levels of the different trace elements at the 12 th week of lactation infer that other influencing factors may be important. Considering the fact that these mothers were entirely breast-feeding their babies, the stress of lactation might have been a contributory factor to the persistently low plasma $\mathrm{Zn}$ levels during the first 3 months post-partum. This view is supported by results of studies which indicate that stress to normal animals is accompanied by a reduction in plasma $\mathrm{Zn}$ concentration (Weinberg, 1974; Chesters \& Will, 1981). In fact, as observed by Chesters \& Will (1981), the effects of stress to normal animals can result in a reduction of plasma $\mathrm{Zn}$ concentration comparable with that associated with dietary $\mathrm{Zn}$ deficiency. Contrary to our present observations, Moser \& Reynolds (1983), in a study on lactating American women, reported higher plasma $\mathrm{Zn}$ levels which were not significantly different from those of a control group (consisting of women who had just given birth to babies but were not lactating) during the first 6 months post-partum. Although that study involved lactating women, it was not clear from the information given to what extent breast milk constituted the food intake of their babies during the study period. That the stress of lactation is greater in a woman entirely breast-feeding her baby than in one who includes supplements to breast-feeding cannot be denied. In addition, the subjects in that study were better nourished in respect of $\mathrm{Zn}$ and especially protein intake. Blood loss at parturition is common and certainly reduces the total plasma $\mathrm{Zn}$ and $\mathrm{Fe}$ in the circulation and thus could also be regarded as a contributory factor to the observed low levels.

Plasma $\mathrm{Cu}$ levels were, on average, higher in lactating subjects than in the controls. This may be due to the fact that plasma $\mathrm{Cu}$ is usually raised in pregnancy (Mason, 1979) and takes some time to fall back to normal levels post-partum. While reports in the literature suggest that the fall in plasma $\mathrm{Cu}$ levels post-partum may take less than 1 month (Nielsen, 1944), the present results seem to suggest that the duration of the fall may be longer in Nigerians entirely breast-feeding their young. Classically, the fall in plasma $\mathrm{Cu}$ levels following delivery may be explained by the occurrence of such physiological adjustments as the cessation in the production of the oestrogenic stimuli for the synthesis of caeruloplasmin (the major form in which $\mathrm{Cu}$ is carried in the blood). Oestrogen levels were not measured in the present subjects and thus the exact extent of influence of this hormone on the observed plasma Cu levels is not known. On the other hand, since stress conditions have been reported to give rise to high serum $\mathrm{Cu}$ levels (Beisel \& Pekarek, 1972) it is likely, also, that the high stress of lactation (especially in the circumstances of the present study where infants were being entirely breast-fed) may be a contributory factor influencing the fall in plasma $\mathrm{Cu}$ levels post-partum.

The observed mean dietary $\mathrm{Zn}$ intake of $8.2 \mathrm{mg} / \mathrm{d}$ was much higher than the value of $6.8 \mathrm{mg} / \mathrm{d}$ reported earlier for a group of four rural Nigerian women of undefined lactating age (Mbofung \& Atinmo, 1980). The values were, however, lower than that of $11.2 \mathrm{mg} / \mathrm{d}$ reported by Geissler $e t$ al. (1978) for lactating Iranian women from a low socio-economic group and that of $13.7 \mathrm{mg} / \mathrm{d}$ reported for lactating Finnish women in the 6th and 8th weeks of lactation (Vuori et al. 1980). The values were also lower than those of 9.4 and $12.8 \mathrm{mg} / \mathrm{d}$ for American women in the 1st and 3rd months of lactation respectively (Moser \& Reynolds, 1983). Although the dietary $\mathrm{Zn}$ intake of lactating mothers was higher than that of the non-lactating, non-pregnant group, it was significantly lower than the recommended dietary intake level of $28.0 \mathrm{mg} / \mathrm{d}$. The observed levels of intake thus confirm earlier speculation 
that lactating mothers in this environment consume marginal to deficient levels of dietary $\mathrm{Zn}$ when compared with the RDA (Mbofung \& Atinmo, 1980). In agreement with earlier observations (Mbofung \& Atinmo, 1980; Hunt et al. 1979; Anderson et al. 1981; Gibson $\&$ Scythes, 1982), $\mathrm{Zn}$ was highly correlated with protein $(r 0.65)$ in the diet. The correlation. between dietary and plasma $\mathrm{Zn}$ levels suggests that individuals on high $\mathrm{Zn}$ intake levels (by implication, well-nourished individuals) had high plasma $\mathrm{Zn}$ levels. Reports of plasma $\mathrm{Zn}$ levels of lactating American women consuming much larger amounts of $\mathrm{Zn}(12.8 \mathrm{mg} / \mathrm{d})$ and protein $(86 \mathrm{~g} / \mathrm{d})$ than those in the present study suggest this kind of relation (Moser \& Reynolds, 1983). In the study by Moser \& Reynolds (1983), plasma $\mathrm{Zn}$ levels of the lactating women were higher than those in the present study $(876 v .684 \mu \mathrm{g} / \mathrm{l})$ in the $3 \mathrm{rd}$ month post-partum.

The results of the present study also tend to confirm earlier speculation that most daily intakes of $\mathrm{Cu}$ by rural Nigerian women are low (Mbofung \& Atinmo, 1982). The mean $\mathrm{Cu}$ intake of $1.6 \mathrm{mg} / \mathrm{d}$ for the lactating mothers fell below the range of values for daily $\mathrm{Cu}$ intakes (1.7-2.4 mg/d) from self-selected western diets (Waslien, 1976). The mean value was also lower than the value of $1.88 \mathrm{mg} / \mathrm{d}$ reported by Vuori et al. (1980) for lactating Finnish women but slightly higher than the value of $1.5 \mathrm{mg} / \mathrm{d}$ reported by Geissler $e$ al . (1978) for poor, lactating Iranian women. A RDA for $\mathrm{Cu}$ is not available owing to the lack of experimentally acquired values for $\mathrm{Cu}$ metabolism in human lactation. Based on the estimates of Geissler et al. (1978) that $2 \mathrm{mg} \mathrm{Cu} / \mathrm{d}$ is adequate for lactation, the observed levels of intake were grossly inadequate. Studies in animals indicate that inadequate $\mathrm{Cu}$ intakes can influence milk $\mathrm{Cu}$ levels (Underwood, 1971) and, where infants are given $\mathrm{Cu}$-deficient milk, they exhibit symptoms of anaemia, neutropenia, skeletal and connective tissue changes (Underwood, 1971). Although corresponding human studies have not been widely reported, the importance of adequate $\mathrm{Cu}$ intake during lactation is implied.

The mean Fe intake $(29.0 \mathrm{mg} / \mathrm{d})$ of the lactating mothers was very similar to levels reported by Abakada \& Hussain (1980). Most diets in Nigeria are high in $\mathrm{Fe}$ content. One issue that has not yet been investigated here, however, is the availability of the dietary $\mathrm{Fe}$ in the process of absorption. The analysis of dietary information according to groups based on nutritional status as indexed by haemoglobin levels indicated a significant variation in $\mathrm{Fe}$ intake of the different groups. Although the Fe intake in the group of low haemoglobin status was as high as $27.0 \mathrm{mg} / \mathrm{d}$, the mean haemoglobin level was only $9.0 \mathrm{~g} / \mathrm{l}$; this may have been due to poor bioavailability of ingested Fe. Analysis of plasma trace elements, on the other hand, indicated that subjects with low haemoglobin (low nutritional status) had equally low plasma $\mathrm{Zn}, \mathrm{Cu}$ and $\mathrm{Fe}$ levels. While the importance of these three elements in the metabolism of haemoglobin has been reported in the literature (Mason, 1979), evidence from studies in Niger by Murray et al. (1978) shows that the serum Fe status of breast-fed infants as well as the concentration of Fe in breast milk are independent of the Fe status of the mother.

In agreement with the observations of Hambidge et al. (1983), $\mathrm{Zn}$ and $\mathrm{Fe}$ intakes were both significantly correlated with protein and energy intakes. A similar relation was observed for $\mathrm{Cu}$, energy and protein. Furthermore, the observation of a significant correlation between dietary and plasma $\mathrm{Zn}$ and $\mathrm{Fe}$ suggests that improved dietary intake leads to higher plasma levels of those nutrients. In looking at these relations, it is worthwhile to note that in studies of this nature the interpretation of the correlation between plasma and dietary levels of any nutrient can at best be speculative since factors other than diet (such as relative availability from body stores and the effect of milk synthesis) influence plasma levels. This probably explains the low correlation obtained and hence the fact that only about $6.8 \%\left(r^{2} 0.068\right)$ of plasma $\mathrm{Zn}$ levels and less than $3 \%$ of plasma Fe levels $\left(r^{2} 0.029\right)$ can be attributed directly to dietary levels of the respective nutrients. 
Despite the apparently low levels of trace element intake, evidence from studies on the Fe status of Niger mothers and their infants show that the breast-milk Fe content of lactating mothers is independent of their Fe status (Murray et al. 1978) and that infants entirely breast-fed were observed to grow normally. This observation is in agreement with other reports (Jackson et al. 1964; Omololu et al. 1981). In lactation the maternal body probably has an enhanced and efficient mechanism for the absorption and utilization of trace elements in milk synthesis. On the other hand, the adequacy of lactation as indexed by the growth of the infant and the occurrence of low plasma trace element levels during lactation tends to suggest that milk biosynthesis has a priority in the distribution of circulating plasma trace elements. Furthermore, it appears that in a situation where dietary nutrient intakes are low and mothers are entirely breast-feeding their young, the stress of lactation seems to be accompanied by low plasma $\mathrm{Zn}$ and $\mathrm{Fe}$ and high plasma $\mathrm{Cu}$ levels. This needs further investigation. Also, there is a need to determine the efficiency of trace element utilization during human lactation. Information from such studies will be useful in the reassessment or calculation of RDA for the different trace elements.

\section{REFERENCES}

Abakada, A. O. \& Hussain, M. A. (1980). Ecology of Food and Nutrition 10, 105-111.

Anderson, B. M., Gibson, R. S. \& Sabry, J. H. (1981). American Journal of Clinical Nutrition 34, $1042-1048$.

Atinmo, T., Mbofung, C. \& Osinusi, B. O. (1980). International Journal of Gynaecology and Obstetrics 8, $454-464$.

Beisel, M. R. \& Pekarek, R. S. (1972). International Review of Neurobiology 1 (Suppl.), 53-60.

BMDP (1979). Biomedical Computer Programmes P. Series [N. J. Dixon and M. B. Brown, editors]. Berkeley: University of California Press.

Butrimovitz, C. P. (1977). The determination of plasma zinc by atomic absorption spectrophotometry. PhD Thesis, University of Maryland.

Chesters, J. K. \& Will, M. (1981). British Journal of Nutrition 46, 119-130.

Food and Agriculture Organization (1957). FAO Nutrition Studies no. 15. Rome: FAO.

Food and Agriculture Organization/World Health Organization (1973). FAO/WHO Reports Series no. 52. Rome/Geneva: FAO/WHO.

Geissler, C., Calloway, D. H. \& Margen, S. (1978). American Joumal of Clinical Nutrition 31, $341-354$.

Gibson, R. S. \& Scythes, C. A. (1982). British Journal of Nutrition 48, 241-248.

Halsted, J. A., Hackley, B. M. \& Smith, J. C. (1968). Lancet ii, 278.

Hambidge, K. M. \& Droegmueller, W. (1974). Obstetrics and Gynaecology 44, 666-672.

Hambidge, K. M., Krebs, N. F. \& Jacobs, M. A., Favier, A., Pham, D., Guyette, L. \& Ikle, D. N. (1983). American Journal of Clinical Nutrition 37, 429-442.

Hunt, I. F., Murphy, N. J., Gomez, J. \& Smith, J. C. (1979). American Journal of Clinical Nutrition 32, 1511 -1518. International Committee for Standardization in Haematology (1967). Journal of Haematology 13 (Suppl.), $71-73$. Jackson, R. L., Westerfield, R., Chopra, M. A., Kimball, R. A. \& Lewis, R. B. (1964). Pediatrics 33, $643-647$. Jameson, S. (1976). Acta Medica Scandinavica (Suppl.), 593.

Jelliffe, D. B. (1966). The Assessment of the Nutritional Status of the Community, World Health Organization Monograph Series no. 53. Geneva: WHO.

Karmarkar, M. G. \& Ramakrishnan, C. U. (1960). Acta Paediatrica Scandinavica 49, 559--564.

McPherson, I. G. \& Everard, J. W. (1972). Clinical Chimie Acta 37, 117-121.

Mason, K. E. (1979). Journal of Nutrition 109, 1979-2066.

Mbofung, C. M. F. \& Atinmo, T. (1980). Nigerian Journal of Nutritional Sciences 1, 14-19.

Mbofung, C. M. F. \& Atinmo, T. (1982). Nutrition Reports International 26, 767-774.

Moser, P. B. \& Reynolds, R.D. (1983). American Journal of Clinical Nutrition 38, 101-108.

Murray, M. J., Murray, A. B., Murray, N. J. \& Murray, M. B. (1978). British Journal of Nutrition 39, $627-630$.

Nielsen, A. L. (1944). Acta Medica Scandinavica 118, 92-96.

Omololu, A., Hussain, M. A. \& Mbofung, C. M. F. (1981). Nigerian Journal of Paediatrics 81, 70-78.

Picciano, M. \& Guthrie, H. (1976). American Journal of Clinical Nutrition 29, 242-248.

Schraer, K. K. \& Calloway, D. H. (1974). Nutrition and Metabolism 17, 205-210.

Underwood, E. J. (1971). Trace Elements in Human and Animal Nutrition. New York: Academic Press.

Vaughan, L. A., Weber, C. W. \& Kemberling, S. R. (1979). American Journal of Clinical Nutrition 32, $2301-2306$. Vuori, E., Makinen, S. M., Kara, R. \& Kuitunen, P. (1980). American Journal of Clinical Nutrition 33, $227-231$.

Waslien, C. I. (1976). In Trace Elements in Human Health and Disease, pp. 347-370. [A. S. Prasad, editor]. New York: Academic Press. 
Weinberg, E. D. (1974). In Trace Element Metabolism in Animals - 2, p. 241-254. [W. G. Hoekstra, J. W. Suttie, H. E. Ganther and W. Mertz, editors]. Baltimore, Maryland: University Park Press.

World Health Organization (1970). Requirements of Ascorbic Acid, Vitamin D, Vitamin B ${ }_{12}$, Folate and Iron. Technical Report Series no. 452. Geneva: WHO.

World Health Organization (1973). Trace Elements in Human Nutrition. Technical Report Series no. 532. Geneva: WHO.

Zaino, E. C. (1967). Atomic Absorption Newsletter 6, 93-95. 